\title{
The role of sea ice formation in cycling of aluminium in northern Marguerite Bay, Antarctica
}

\author{
Katharine R Hendry 1 \\ Michael P Meredith ${ }^{2}$ \\ Christopher I Measures ${ }^{3}$ \\ Damien S Carson ${ }^{4}$ \\ Rosalind E M Rickaby ${ }^{5}$
}

1 Department of Marine Chemistry and Geochemistry, Woods Hole Oceanographic Institution, Woods Hole Road, Woods Hole, MA 02543, USA

2 British Antarctic Survey, High Cross, Madingley Road, Cambridge CB3 0ET, UK

${ }^{3}$ Department of Oceanography, University of Hawaii, 1000 Pope Road, Honolulu, HI 96822, USA

${ }^{4}$ School of Geosciences, University of Edinburgh, Grant Institute, The King's Buildings, West Mains Road, Edinburgh EH9 3JW, UK

${ }^{5}$ Department of Earth Sciences, University of Oxford, Parks Road, Oxford OX1 3PR, UK

\section{Abstract}

The use of dissolved $\mathrm{Al}$ as a tracer for oceanic water masses and atmospheric dust deposition of biologically important elements, such as iron, requires the quantitative assessment of its sources and sinks in seawater. Here, we address the relative importance of oceanic versus atmospheric inputs of $\mathrm{Al}$, and the relationship with nutrient cycling, in a region of high biological productivity in coastal Antarctica. We investigate the concentrations of dissolved $\mathrm{Al}$ in seawater, sea ice, meteoric water and sediments collected from northern Marguerite Bay, off the West Antarctic Peninsula, from 2005-2006. Dissolved Al concentrations at $15 \mathrm{~m}$ water depth varied between 2 and $27 \mathrm{nM}$, showing a peak between two phytoplankton blooms. We find that, in this coastal setting, 
upwelling and incorporation of waters from below the surface mixed layer are responsible for this peak in dissolved $\mathrm{Al}$ as well as renewal of nutrients. This means that changes in the intensity and frequency of upwelling events may result in changes in biological production and carbon uptake. The waters below the mixed layer are most likely enriched in $\mathrm{Al}$ as a result of sea ice formation, either causing the injection of Al-rich brines or the resuspension of sediments and entrainment of pore fluids by brine cascades. Glacial, snow and sea ice melt contributes secondarily to the supply of Al to surface waters. Total particulate Al ranges from 93 to $2057 \mu \mathrm{g} / \mathrm{g}$, and increases with meteoric water input towards the end of the summer, indicating glacial runoff is an important source of particulate $\mathrm{Al}$. The $(\mathrm{Al} / \mathrm{Si})_{\text {opal }}$ of sediment core top material is considerably higher than water column opal collected by sediment traps, indicative of a diagenetic overprint and incorporation of $\mathrm{Al}$ at the sediment-water interface. Opal that remains buried in the sediment could represent a significant sink of $\mathrm{Al}$ from seawater.

\section{Keywords}

Biogeochemistry; nutrients (mineral); trace metals; brines; Antarctica

\section{Introduction}

Aluminium (Al) is the third most abundant element in crustal materials, and is released into seawater from fluvial and glacial runoff, hydrothermal activity, aerosols and sediment diagenesis. However, concentrations of dissolved $\mathrm{Al}$ in seawater are disproportionately low as a result of rapid scavenging and uptake 
by particles (Orians and Bruland, 1986; Vink and Measures, 2001). Quantifying the geochemical behaviour of $\mathrm{Al}$ in seawater is important for our understanding of the biogeochemical cycling of other elements, such as silicon (Si) and iron (Fe), which share some common input and output processes. However, there remain several unanswered questions regarding the Al budget of the oceans. What is the relative importance of different inputs and outputs of Al to the oceans? Do these processes show geographical variations, for example in high versus low latitudes? How do these processes influence macro and micronutrients, and how might future changes in these processes affect biogeochemical cycling?

\subsection{Inputs of Al and its use as a dust tracer}

In most open ocean regions, $\mathrm{Al}$ inputs to the surface ocean are dominated by atmospheric deposition of mineral dust (Vink and Measures, 2001). Approximately $2 \times 10^{15} \mathrm{~g}$ of dust is deposited into the oceans per year (Ginoux et al., 2001); assuming an $\mathrm{Al}$ content of dust 2-8\%, and a solubility of 3-9\% (Baker et al., 2006), this dust deposition equates to approximately $1 \times 10^{13} \mathrm{~g}$ of dissolved $\mathrm{Al} \mathrm{yr}^{-1}$. This is at least two orders of magnitude lower than riverine

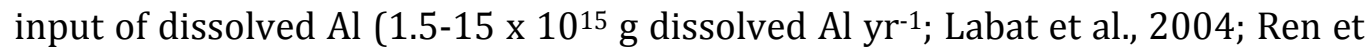
al., 2006).

Previous studies have explored the potential for using dissolved $\mathrm{Al}$ concentration in open ocean surface waters as a proxy for atmospheric inputs of mineral dust and by extension biologically important metals, such as Fe (Measures and Brown, 1996; Vink and Measures, 2001; Measures et al., 2005).

Despite a good correspondence between dissolved $\mathrm{Al}$ and Fe concentrations in 
some open ocean regions, such as the South Atlantic (Vink and Measures, 2001), the use of dissolved $\mathrm{Al}$ concentration as an oceanic proxy for Fe still requires further understanding of the relative dissolution of these elements from mineral dust, and the role of other input processes in controlling dissolved $\mathrm{Al}$ distribution in the oceans. Other sources of dissolved Al to deep waters are hydrothermal activity (Von Damm, 1995) and diagenetic release from sediments (Chou and Wollast, 1997), which appears to show significant geographical variations (Stoffyn-Egli, 1982; Mackin and Aller, 1984; Micholpoulos and Aller, 1995, 2004). An additional source of Al to subsurface waters in high latitudes is the rejection of brines, which are high salinity and high density fluids formed during sea ice formation (Measures and Edmond, 1992).

\subsection{Al uptake: scavenging and the role of biogenic opal}

Outputs of $\mathrm{Al}$ from the ocean are dominated by scavenging, resulting in a short residence time of $\mathrm{Al}$ in seawater, which is particularly rapid in coastal regions (Orians and Bruland, 1986; Measures and Edmond, 1990; Vink and Measures, 2001; Ren et al., 2006). Although variable and population dependent, the uptake of $\mathrm{Al}$ by algal blooms in these regions can result in significant seasonal variation in the concentration of dissolved $\mathrm{Al}$ in surface waters (Hydes, 1989; van Beusekom et al., 1997; Hall et al., 1999; Koshikaura and Hori, 2002; Measures et al., 2005).

One important sink of $\mathrm{Al}$ is biogenic silica (opal). $\mathrm{Al}$ is taken up by opal through adsorption (Moran and Moore, 1992) and structural incorporation of up to $\sim 1.3 \%$ (Gehlen, 2002). Al is thought to migrate into opal after deposition, stabilising the structure and reducing solubility (van Bennekom et al., 1981, 
1989, 1991; Dixit et al., 2001; Dixit and van Cappellen, 2002; Rickert et al., 2002;

Koning et al., 2007). This migration implies biogenic opal could represent a significant sink of $\mathrm{Al}$ in sediments.

The purpose of this paper is to examine cycling of $\mathrm{Al}$ in a high latitude coastal system, in particular the source of Al to the surface waters, and the behaviour of Al during a phytoplankton bloom dominated by diatoms. Here, we carry out a study of dissolved and particulate $\mathrm{Al}$ in coastal seawater off the West Antarctic Peninsula (WAP), which is a region of high biological productivity. We investigate the uptake of $\mathrm{Al}$ into biogenic opal, and assess its role as a source and sink of $\mathrm{Al}$ in coastal waters. This region provides an ideal testing ground for natural seasonal variations in $\mathrm{Al}$ concentration away from significant anthropogenic pollution.

\section{Field setting}

Coastal seawater samples were collected from Ryder Bay, a small embayment within the larger Marguerite Bay on the WAP Shelf (Figure 1). This is close to the British Antarctic Survey (BAS) Rothera Research Station, on Adelaide Island. Marguerite Bay experiences some of the highest biomass concentrations along the WAP (Clarke et al., 2008). The WAP is one of the three most rapidly warming regions in the world, and the only to be situated in the Southern Hemisphere. Further, it is the only one of the three regions with a maritime climate, and so is the ideal case study of the impacts of rapid atmospheric and cryospheric change on the physical and biogeochemical systems of the ocean (Meredith and King, 2005). Ryder Bay is part of several long term monitoring projects (e.g. Rothera Oceanographic and Biological Time Series, RaTS; Clarke et 
al., 2008; www.antarctica.ac.uk/rats). The RaTS site is located $4 \mathrm{~km}$ off shore and has an approximate water depth of $520 \mathrm{~m}$. The sampling site is sea ice-free during austral summer, with winter fast-ice formation typically beginning in May-June (Meredith et al., 2008).

The Antarctic Circumpolar Current (ACC) delivers nutrient-rich, oxygen poor, warm water in the form of Upper Circumpolar Deep Water (UCDW) onto the continental shelf along the WAP and into Marguerite Bay at irregular times throughout the year (Moffat et al., 2009). In winter, a deep homogenous mixed surface layer overlies the UCDW, created due to late autumn and winter cooling, sea ice formation and sinking of dense, cold waters (Meredith et al., 2004). In summer, insolation and ice melt act to warm and freshen the very surface layer; this overlies the remnant of the winter mixed layer, which survives as a subsurface temperature minimum termed the Winter Water Mass (WW). The generic term for WW and the overlying mixed layer is Antarctic Surface Water (AASW). WW is separated from the overlying mixed layer in summer by a strong pycnocline, which typically persists until autumn when convective overturn of the upper ocean induced by sea ice production deepens the mixed layer once more. However, there is a degree of mixing across the pycnocline in other seasons, associated with meteorological forcing and other phenomena (Meredith et al., 2004, 2008; Clarke et al., 2008; Wallace et al., 2008).

\section{Methods}

Water samples were pumped 2-3 times a week throughout the austral summer 2005-2006 from 15m depth at the RaTS site (the average depth of the chlorophyll $a$, or chl $a$, maximum; Clarke et al., 2008) through metal-free tubing 
into pre-cleaned containers. $250 \mathrm{~mL}$ of seawater were filtered under clean conditions at Rothera Research Station through a pre-cleaned 0.2 micron polycarbonate membrane (Whatman) using a metal-free filter housing and stored in polypropylene bottles. Interstitial waters were sampled from sea ice by sackhole drilling in spring 2005 and filtered as above (full details are given in Hendry et al., 2009). Briefly, the sea ice surface was scraped with a plastic edge to remove surface snow. Then a hole was drilled, covered and left for a few minutes. The first interstitial waters that filled the hole were removed using a clean, plastic beaker to prevent contamination from the drill (Hendry et al,. 2009), prior to sampling into pre-cleaned plastic containers. Glacier and snow melt-waters were also collected into pre-cleaned plastic containers for analysis in late summer 2006. Dissolved Al concentration was measured on board the R/V Nathaniel B Palmer using an automated Flow Injection Analytical system (FIA; Resing and Measures, 1994). A laboratory blank of $18 \mathrm{M} \Omega . \mathrm{cm}$ Milli-Q water was filtered through the apparatus, and was found to be below the limit of detection $(\sim 0.4 \mathrm{nM})$. This method has a typical precision at these concentrations of Al of 1-2\% (Vink and Measures, 2001). Dissolved nutrients were analyzed from water samples filtered through GF/F and polycarbonate filters (Whatman) using a Skalar autoanalyser at the University of East Anglia, and results have been reported elsewhere (Hendry et al., 2008). Samples for nitrate and phosphate analysis were frozen immediately after filtration; samples for silicic acid analysis were transported at $+4^{\circ} \mathrm{C}$.

Additional water samples were collected routinely, sealed and transported to the UK for stable isotope $\left(\delta^{18} 0\right)$ analysis as a continuation of the time-series 
discussed in Meredith et al. (2008). The relative contribution of meteoric and sea ice melt can be determined using mass balance calculations based on salinity and $\delta^{18} 0$ measurements from the $15 \mathrm{~m}$ sampling depth (Meredith et al., 2008; Equations 1-3, where $f$ is the fraction of oceanic water (cdw), sea ice melt (sim) and meteoric water (met), $\delta^{18} \mathrm{O}$ is the oxygen isotopic composition with respect to SMOW, and S are the respective salinities).

$$
\begin{aligned}
& f_{c d w}+f_{s i m}+f_{m e t}=1 \\
& f_{c d w} S_{c d w}+f_{s i m} S_{s i m}+f_{m e t} S_{m e t}=S \\
& f_{c d w} \delta^{18} O_{c d w}+f_{s i m} \delta^{18} O_{s i m}+f_{m e t} \delta^{18} O_{m e t}=\delta^{18} O
\end{aligned}
$$

Duplicate samples of approximately $10 \mathrm{~L}$ of seawater collected from $15 \mathrm{~m}$ at the RaTS site, allowing a comparison of total (labile and refractory) Al associated with bulk particulate matter, and refractory Al incorporated into silicates (lithogenic and biogenic). One $10 \mathrm{~L}$ sample was filtered through $142 \mathrm{~mm} 0.2$ micron polycarbonate membranes (Whatman) to collect total biogenic material; the other $10 \mathrm{~L}$ sample was filtered through 0.45 micron polycarbonate membranes (Whatman) to collect bulk particulates. Material was subsequently removed from the 0.2 micron filters at the University of Oxford by sonicating in $18 \mathrm{M} \Omega . \mathrm{cm}$ Milli-Q water. The filter was removed and solids separated by centrifugation. The solid residue was cleaned for organic matter and carbonates by heating in $10 \%$ reagent grade $\mathrm{H}_{2} \mathrm{O}_{2}$ (Analar) and $10 \% \mathrm{HCl}$ for half an hour each respectively. The remaining silicates were then cleaned using a published protocol (Hendry and Rickaby, 2008). Briefly, the cleaned silicates were 
reductively cleaned by heating in $0.1 \%$ hydroxylamine chloride in acetic acid, then heated in $1 \% \mathrm{NaF}$ etching solution, then heated in a 50:50 mixture of inhouse distilled $\mathrm{HNO}_{3}: \mathrm{HCl}$ solution, before being rinsed in $18 \mathrm{M} \Omega . \mathrm{cm}$ Milli-Q water. The silicates were then dissolved in dilute in-house distilled HF at room temperature, and diluted in $1 \%$ in-house distilled $\mathrm{HNO}_{3}$ for analysis. Si concentration checks were carried out, followed by trace metal analysis, at the University of Oxford using Quadrupole Inductively-Coupled Plasma Mass Spectrometry (Q-ICP-MS; Perkin Elmer Elan 6100DRC). The Al content of the total silicate fraction (lithogenic and biogenic material) is reported normalized to $\mathrm{Si}$, defined as $(\mathrm{Al} / \mathrm{Si})_{\text {total. }}$.

Total particulate $\mathrm{Al}$ was extracted from the 0.45 micron filters using digestion in $\mathrm{HF} / \mathrm{HNO}_{3} / \mathrm{HCl}$ (Romil ultra-pure), and analyzed by Vista Pro ICP-OES at the University of Edinburgh. Analytical precision is better than 2\% (Ganeshram et al., 2003).

Two instrumented mooring arrays were deployed in Marguerite Bay from the RRS James Clark Ross in January 2005 (Figure 1), at the RaTS site and to the south at a deeper site (820 m water depth). Each mooring held oceanographic instrumentation and two sediment traps, at $200 \mathrm{~m}$ and $400 \mathrm{~m}$ for the shallow mooring and $123 \mathrm{~m}$ and $745 \mathrm{~m}$ for the deeper mooring (Wallace et al., 2008; Weston et al., in prep.). The time-series traps were configured to sample sinking particles throughout the year at fortnightly to bimonthly periods (Weston et al., in prep). Opal was extracted from the recovered sediments, cleaned and analyzed for Al content using published protocol, normalized to Si and reported 
as $(\mathrm{Al} / \mathrm{Si})_{\text {opal }}$ (Hendry and Rickaby, 2008). Core top sediments from the mooring sites have previously been analyzed for (Al/Si) opal (Hendry and Rickaby, 2008).

\section{Results}

Dissolved Al concentrations ranged from 2 to $27 \mathrm{nM}$ throughout the austral summer (Figure 2). The lowest dissolved $\mathrm{Al}$ concentrations were found during the early spring bloom, during which chl a concentrations reached approximately $25 \mathrm{mg} \mathrm{m}^{-3}$ (Clarke et al,. 2008; Hendry et al., 2008), followed by the highest values of dissolved Al concentrations concurrent with a decline in chl a during late January. In early February, dissolved $\mathrm{Al}$ concentrations declined to 5-10 nM, whilst chl $a$ remained low (10-15 $\mathrm{mg} \mathrm{m}^{-3} \mathrm{chl} a$ concentrations). The dissolved Al concentrations from sea ice interstitial waters ranged from 17 to 42 nM (Table 1). Seawater underlying the sea ice showed dissolved Al concentrations ranging from 8 to $10 \mathrm{nM}$ (Table 1), consistent with measurements made during the ice-free summer. Glacier and snow melt dissolved $\mathrm{Al}$ concentrations were 72 and $98 \mathrm{nM}$ respectively. Total particulate $\mathrm{Al}$ ranged from 92 to $2056 \mu \mathrm{g} / \mathrm{g}$ in filtered seawater samples (Figure 2), and increased later in the season. There was a slight decrease in bulk particulate $\mathrm{Al}$ at the beginning of March during the second bloom, probably as a result of dilution of lithogenic material by biogenic particles. Total particulate Al from filtered sea ice samples range from 150 to $690 \mu \mathrm{g} / \mathrm{g}$. (Al/Si) total ratios in silicates filtered from the water column ranged from 2000 to $14000 \mu \mathrm{g} / \mathrm{g}$ (Figure 2).

Full details of particle fluxes from the sediment traps are reported elsewhere (Weston et al., in prep). Opal extracted from the sediment traps showed $(\mathrm{Al} / \mathrm{Si})_{\text {opal }}$ ratios of 20 to $283 \mu \mathrm{g} / \mathrm{g}$ (Figure 3 ). 


\section{Discussion}

\subsection{Comparison of dissolved Al concentration with other coastal Antarctic regions}

Our dissolved $\mathrm{Al}$ concentration concentrations from northern Marguerite Bay are consistent with published values for the Weddell Sea, ranging from 8-22 nM (van Bennekom et al., 1991; Sañudo-Wilhelmy et al., 2002) and other coastal regions (Hydes and Liss, 1977; Hydes, 1989), but are lower than other regions of nearshore WAP, including 660 nM near Deception Island, 50-355 nM Palmer Station (Sañudo-Wilhelmy et al., 2002) and 60-200 nM at King George Island (Prendez et al., 2003).

The dissolved Al concentration measurements from the glacial and snow melt correspond well to the lower range of values measured in WAP ice cores (2-6 ppb, or 75-200 nM; McConnell et al., 2007). Total dissolved Fe concentrations from glacial meltwater in Greenland range from $22.4 \mathrm{nM}(<0.03 \mu \mathrm{m}$ filtered $)$ to $30.8 \mathrm{nM}$ (0.03-0.4 nM; Statham et al., 2008), which, if comparable to glacial melt in the southern high latitudes, is consistent with crustal Al:Fe of $\sim 3.5$ (Vink and Measures, 2001).

\subsection{Sources of dissolved Al to surface waters in Marguerite Bay}

Sources of dissolved $\mathrm{Al}$ to coastal water include continental runoff, atmospheric deposition and upwelling or mixing with underlying waters, whilst scavenging and incorporation into particles dominate the removal processes.

The highest dissolved Al concentration occurred in a pulse at the end of January, after the first chl $a$ peak. Chl $a$ is a function of biomass, and the chl a peak represents the early spring phytoplankton bloom (Clarke et al., 2008; Figure 2). 
We suggest this high dissolved Al input was a result of underlying water upwelling and/or mixing, as opposed to meteoric or atmospheric input. We can eliminate continental runoff, which is dominated by glacial melt-water in this region, as a source of this pulse using salinity and seawater $\delta^{18} 0$. Similarly to previous years, the contribution of meteoric water into Marguerite Bay ranged between 2-5\%, and sea ice melt was lower at 1\% (Figure 4A; Meredith et al., 2008). Assuming the meteoric water dissolved $\mathrm{Al}$ concentration is approximately $100 \mathrm{nM}$ as measured in the snow-melt and glacier-melt samples, the maximum contribution to surface water is $5 \mathrm{nM}$ compared with an increase of $\sim 18 \mathrm{nM}$ over $\sim 12$ days. It is possible that meteoric inputs of greater $\mathrm{Al}$ concentrations, of approximately $400 \mathrm{nM}$, could explain the pulse of dissolved Al. However, these values are higher than those measured in this study and, at the time of the dissolved $\mathrm{Al}$ pulse, the meteoric water input is at its lowest (Figure 4A). There is a slight increase in sea ice melting at this time. However, sea ice melting is not expected to contribute a significant amount of dissolved $\mathrm{Al}$ during spring/summer as the total contribution from melting is not likely to exceed the $\mathrm{Al}$ concentration of the seawater from which the ice froze (1-2 nM). The melting of sea ice that froze from seawater with a significant run-off component (i.e. formed nearshore) could contribute more Al, but the melt-water would retain a meteoric $\delta^{18} 0$ signature, which is not observed. Although meteoric water is not responsible for the high Al pulse in early February, there is insufficient data to exclude an increase in dissolved Al to surface waters in the late summer/autumn as a result of glacial input. There is a clear link between bulk particulate $\mathrm{Al}$ and both salinity (Figure 2) and meteoric water input in late February/early March (Figure 4A). This indicates meteoric input is important 
for particulate $\mathrm{Al}$ input, most likely via particulates in glacial and sea ice meltwater.

Atmospheric input, through dissolution of mineral dust, can arise as a result of direct particle settling onto the seawater surface or via precipitation and subsequent sea ice melt. In particular, there is an increase in sea ice melt at the time of the high Al pulse. However, for this sea ice melt to result in the observed increase in $\mathrm{Al}$ concentration, the original sea ice would have to contain an equivalent of over $1 \mu \mathrm{M}$ dissolved $\mathrm{Al}$, which is at least an order of magnitude greater than the measured concentration in the snow-melt samples. Furthermore, we can use variations in the Mixed Layer Depth (MLD) to assess the depth of mixing of any signal derived from the atmosphere. The MLD is calculated using the potential density anomaly $\left(\sigma_{0}\right.$, where $\sigma_{0}=\rho-1000$ and $\rho$ is density in $\mathrm{kgm}^{-3}$ ), defined by $\sigma_{0}=\sigma_{0}($ surface $)+0.05$ (Clarke et al., 2008), and is essentially the depth to which the upper ocean is homogenous. The MLD for summer 2005-2006 was shallower than the $15 \mathrm{~m}$ sampling depth until late February (Figure 4B). Hence, any dissolved Al spike resulting from atmospheric input to the surface ocean either directly or through sea ice melting would not mix down to our sampling depth.

The only alternative source of dissolved Al is upwelling and incorporation of water from beneath the mixed layer. Physical oceanographic time series data from the RaTS site provide evidence for upward vertical displacements of property surfaces at the end of January/beginning February, coincident in time with a decrease in biomass (Figure 5). Such vertical fluctuations are often associated with the passage of deeper waters closer to the mixed layer. It is not 
immediately obvious whether such an undulation is simply an upward displacement of density surfaces resulting from the passage of a mesoscale eddy, or whether it has an associated level of mixing across density surfaces. Distinguishing between simple water mass displacement versus surface water alteration by mixing is essential to establish the influence of underlying waters on Al concentration, nutrients and biogeochemical cycling. Some insight into this can be obtained from examining the time series of properties on density surfaces themselves, rather than on depth surfaces as shown in Figure 5. Vertical mixing transfers water across density surfaces, and so appears on a density/time plot as interruptions in the horizontal contours. Figure 6 shows sections of temperature and chl a contoured this way. A steady warming of the WW (centred on the $26.7 \mathrm{~kg} \mathrm{~m}^{-3}$ density surface) can be seen, with some instances of variability embedded within this longer term warming, notably a cooling followed by a warming at the end of January coincident with the decline in biomass. The interruption to the property isopleths on the density surfaces are suggestive of a mixing event, which occurs at the same time as the pulse of dissolved Al, macronutrients and the micronutrient cadmium (Figure 2; Hendry et al., 2008) indicating they are all sourced from upwelling and mixing of deeper waters. If we are correct in our interpretation that upwelling and mixing drives both a temporary drop in biomass, and renews surface concentrations of important nutrients, then possible changes in the frequency of upwelling events could be important for changes in biological productivity and carbon cycling in Marguerite Bay. We cannot establish from the physical data whether the processes we are seeing are internal or external to Marguerite Bay, since they will be occurring an unknown distance upstream of the RaTS site in the WAP 
circulation. However, processes that enhance mixing occur close to the coast in Marguerite Bay, and a significant amount of upwelling and mixing, linked to meterological forcings and internal tides, is known to occur near the RaTS site (Wallace et al., 2008).

\subsection{Sources of Al in water beneath the mixed layer: the role of sea ice}

Although a deep-water source appears the most likely cause of the high Al pulse, previous measurements suggest a low dissolved [Al] in UCDW $(\sim 3 \mathrm{nM}$; Measures and Edmond, 1990), which flows onto the WAP continental shelf (Moffat et al., 2009). This has the implication that there are additional processes that enhance the dissolved $\mathrm{Al}$ concentration of deeper WW water, which are likely a result of sediment diagenesis or sea ice brine rejection. Firstly, Al could be released from shallow sediments during the early diagensis of sediments. However, it is questionable, based on previous studies (Measures and Edmond, 1990, 1992), as to whether sediment diagenesis can impact deep-water dissolved Al concentrations sufficiently to increased subsurface dissolved $\mathrm{Al}$ concentrations to nearly $30 \mathrm{nM}$.

Secondly, brine rejection processes during sea ice formation could enrich the deeper water Al concentration in Marguerite Bay (Measures and Edmond, 1992). The expulsion of brines results in the formation of dense waters, which play an important role in ocean ventilation in the Arctic (Swift and Koltermann, 1988), Antarctic (Gordon, 1998) and North Pacific (Shcherbina et al., 2003; Talley et al., 2003). In Marguerite Bay during winter, the mixed layer deepens due to brine being rejected into the upper ocean. In coastal regions, the sloping sidewalls are sufficiently shallow, such that the dense plumes will encounter the 
seabed, cascade down the sidewall until they reach their level of neutral buoyancy within the WW. There are two possible mechanisms by which sea ice brine rejection could elevate dissolved Al concentration: brine rejection during freezing of high dissolved $\mathrm{Al}$ concentration seawater, in an analogous fashion to the Norwegian Sea Deep Water (Measures and Edmond, 1992), or resuspension of sediment pore fluids from cascading brines (Aagaard et al., 1985).

Sea ice formation early in the previous winter (2005) would have led to the expulsion of Al-rich brines if it froze from water with a high runoff contribution (Measures and Edmond, 1992). The RaTS site is sufficiently close to the site of meteoric melt-water source to experience high dissolved $\mathrm{Al}$ concentration in surface waters before its removal by scavenging. Previous estimates of $\mathrm{Al}$ concentration in brines, ranging from 70-300 $\mathrm{nM}$ (Measures and Edmond, 1990), are higher than the sea ice interstitial waters measured here $(\sim 50 \mathrm{nM})$. However, the samples measured in this study were collected in late winter/early spring (November-December) and were highly diluted $(8.5<\mathrm{S}<20)$ compared to interstitial sea ice waters measured during early and mid-winter. For example, interstitial waters from sea ice collected in August 2006 from Marguerite Bay were of higher salinity (S 90, Hendry et al., 2009), and showed elevated concentrations of other trace metals, such as cadmium, with respect to late winter/early spring 2005 (Hendry et al,. 2009). This suggests high dissolved $\mathrm{Al}$ concentrations are feasible in rejected brines formed during winter ( 250 nM). Alternatively, dissolved Al could be released from sediment pore fluids by resuspension as the brine plumes sink (Aagaard et al., 1985). This mechanism can enrich water beneath the mixed layer with dissolved Al from 
sediment pore fluids, without the need for a large salinity or $\delta^{18} 0$ signal, and does not rely on a high dissolved $\mathrm{Al}$ concentration in the original brines. Furthermore, entrainment of sediments into the sinking brine plumes could increase their density further, allowing deeper injection of pore fluids into the water column.

The scenario for the enrichment of WW water is illustrated in Figure 7. During the previous late summer, glacial melt-water enhanced the particulate $\mathrm{Al}$ content of the water column. In the early winter, brine rejection as this seawater began to freeze elevated the deeper water dissolved $\mathrm{Al}$ concentration either directly or through resuspension of pore fluids. These Al-rich waters mixed periodically in summer (e.g. early Feb 2006) resulting in a surface water $\mathrm{Al}$ concentration spike without causing an instantaneous meteoric $\delta^{18} 0$ peak.

This study only focuses on seawater from one depth at one location, which largely represents the water below the MLD, and so may not be representative in a wider geographic context. However, our data are sufficient to warrant further investigation into enrichment of subsurface waters in dissolved $\mathrm{Al}$ and nutrients by brine rejection. If these processes are ubiquitous to both northern and southern high latitudes, future changes in sea ice formation dynamics may impact high latitude biological productivity and carbon cycling.

\subsection{Scavenging of aluminium}

After the high dissolved $\mathrm{Al}$ concentration peak, concentrations fall back to a baseline of 5-10 nM in early February between the two phytoplankton blooms (Figure 2). Given that there is vertical mixing from deeper waters into the 
surface layer as discussed above in sections 5.2 and 5.3, it is unlikely that the drop in dissolved Al concentration can be explained by advection of water masses alone. Such a rapid drawdown of dissolved Al may be a result of two pathways:

\subsubsection{Scavenging by particulates}

The total particulate matter represents both scavenged and refractory Al, and begins to increase after the dissolved Al peak (Figure 2). This could represent an increase in Al-rich lithogenic particles, and enhanced scavenging of $\mathrm{Al}$.

\subsubsection{Incorporation by particles formed in situ}

The refractory $\mathrm{Al}$ associated with silicates, shown by $(\mathrm{Al} / \mathrm{Si})_{\text {total }}$ (Figure 2), comprises lithogenic material transported into the water column and biogenic opal formed in situ. The lowest values of $(\mathrm{Al} / \mathrm{Si})_{\text {total, which occurs when opal }}$ contributes most to the total refractory silica, and the sediment trap results indicate that diatom growth in the water column can incorporate 100 to 1000 $\mu \mathrm{g} \mathrm{Al}$ per $\mathrm{g}$ Si and could be a significant sink of $\mathrm{Al}$.

\subsection{Uptake by opal: sedimentary sink of Al}

Opal extracted from sediment core tops showed $(\mathrm{Al} / \mathrm{Si})_{\text {opal }}$ ratios (5000 to 26 $000 \mu \mathrm{g} / \mathrm{g}$; Hendry and Rickaby, 2008) that are over an order of magnitude greater than opal from the sediment traps (Figure 3). This demonstrates that biogenic opal becomes enriched in Al very rapidly before burial at or near the sediment-water interface. The incorporation of $\mathrm{Al}$ into sedimentary diatom tests has the implication that buried biogenic opal remaining undissolved in the deeper sediment column is an important sink of Al. For example, a global burial 
rate of 240 Tmol of biogenic opal per year (Tréguer et al., 1995), or approximately $7 \times 10^{15} \mathrm{~g}$ Si per year, would equate to a burial of $\sim 0.1 \times 10^{15} \mathrm{~g} \mathrm{Al}$ per year, at least an order of magnitude greater than the amount of dissolved $\mathrm{Al}$ derived from dust annually.

\section{Conclusions}

Here, we investigated the behaviour of $\mathrm{Al}$ in coastal seawater from a highly productive region of the West Antarctic Peninsula. Dissolved Al concentration showed a pulse between two phytoplankton blooms, and we suggest both the reduction in biomass and sharp increase in both nutrients and dissolved $\mathrm{Al}$ concentration was a result of upwelling and mixing of underlying waters. We suggest the $\mathrm{Al}$ concentration of deeper waters is enriched by brine rejection, with glacial melt-water, sea ice and atmospheric deposition being secondary contributors of dissolved Al to surface waters. Vertical mixing events in this productive coastal location are at least partially responsible for renewing surface waters with nutrients coupled to dissolved $\mathrm{Al}$, such that possible changes in the frequency of these events in the future could have implications for carbon cycling. Future work should focus on establishing how representative Marguerite Bay is of the regional area, and the wider role of sea ice formation for Al cycling in high latitudes.

\section{Acknowledgements}

The authors would like to thank the Rothera Research Station, British Antarctic Survey, marine assistants, Paul Mann and Helen Rossetti for their help in collecting samples as well as the base commander, Andy Clarke, Mags Wallace, other AFI personnel and BAS members of staff for their support. Bathymrety data from M.Brandon (OU); ocean circulation data from C. Moffat and R. Beardsley (WHOI). The authors would like to thank Eric Wolanksi and two anonymous reviewers for insightful comments on the manuscript. RaTS data is 
available from www.antarctica.com/rats. Many thanks to the other members of AFI4-02, Harry Elderfield, Raja Ganeshram, Christina de la Rocha and Samia Mantoura. Nutrient measurements were carried out by Keith Weston (UEA). Thanks also to John Arden and Dave Harding for assistance with the Q-ICP-MS. We would also like to acknowledge the master and crew of the RRS James Clark Ross and the captain and crew of the R/V Nathaniel B Palmer for their assistance in collecting and processing samples. This project is part of AFI4-02 and KRH was funded by NERC grant NER/S/A/2004/12390.

\section{References}

Aagaard, K., Swift, J.H., Carmack, E.C., 1985. Thermohaline circulation in the Arctic Mediterranean Seas. Journal of Geophysical Research 90, 4833-4846.

Baker, A.R., Jickells, T.D., Witt, M., Linge, K.L., 2006. Trends in the solubility of iron, aluminium, manganese and phosphorus in aerosol collected over the Atlantic Ocean. Marine Chemistry 98, 43-58.

Chou, L., Wollast, R., 1997. Biogeochemical behaviour and mass balance of dissolved aluminium in the western Mediterranean Sea. Deep-Sea Research II 44, 741-768.

Clarke, A., Meredith, M.P., Wallace, M.I., Brandon, M.A., Thomas, D.N., 2008. Seasonal and interannual variability in temperature, chlorophyll and macronutrients in Ryder Bay, northern Marguerite Bay, Antarctica. DeepSea Research II (Palmer LTER Special Issue) 55, 1988-2006

Dixit, S., Van Cappellen, P., 2002. Surface chemistry and reactivity of biogenic silica. Geochimica Cosmochimica Acta 66, 2559-2568.

Dixit, S., van Cappellen, P., van Bennekom, A.J., 2001. Processes controlling solubility of biogenic silica and pore water build-up of silicic acid in marine sediments. Marine Chemistry 73, 333-352.

Ganeshram, R.S., Francois, R., Commeau, J., Brown-Leger, S.L., 2003. An experimental investigation of barite formation in seawater. Geochimica Cosmochimica Acta 67, 2599-2605.

Gehlen, M., 2002. Unravelling the atomic structure of biogenic silica: Evidence of the structural association of $\mathrm{Al}$ and $\mathrm{Si}$ in diatom frustrules. Geochimica Cosmochimica Acta 66, 1601-1609.

Ginoux, P., Chin, M., Tegen, I., Prospero, J.M., Holben, B., Dubovik, O., Lin, S.-J., 2001. Sources and distributions of dust aerosols simulated with the GOCART model. Journal of Geophysical Research 106, 20255-20273. 
Gordon, A.L., 1998. Western Weddell Sea thermohaline stratification. S. A. Jacobs and R. F. Weiss, Ocean, Ice and Atmosphere. Interactions at the Antarctic Continental Margin, Antarctic Research Series. AGU, Washington D.C.

Hall, I.R., Hydes, D.J., Statham, P.J., Overnell, J., 1999. Seasonal variations in the cycling of aluminium, cadmium and manganese in a Scottish sea loch: biogeochemical processes involving suspended particles. Continental Shelf Research 19, 1783-1808.

Hendry, K.R., Rickaby, R.E.M., 2008. Opal (Zn/Si) ratios as a nearshore geochemical proxy in coastal Antarctica. Paleoceanography 23. PA2218, doi:10.1029/2007PA001576.

Hendry, K.R., Rickaby, R.E.M., Weston, K., de Hoog, J.C., Rehkämper, M., 2008. Cadmium and phosphate in coastal Antarctic seawater: implications for Southern Ocean nutrient cycling. Marine Chemistry 112, 149-157.

Hendry, K. R., Rickaby, R.E.M., Weston, K., de Hoog, J.C., Rehkämper, M., 2009. The cadmium-phosphate relationship in brine: biological versus physical control over micronutrients in sea ice environments. Antarctic Science doi:10.1017/S0954 102009990381.

Hydes, D., 1989. Seasonal variation in dissolved aluminium concentrations in coastal waters and biological limitation of the export of the riverine input of aluminium to the deep sea. Continental Shelf Research 9, 919-929.

Hydes, D.J., Liss, P.S., 1977. The behaviour of dissolved aluminium and estuarine and coastal waters. Estuarine and Coastal Marine Science 5, 755769.

Koning, E., Gehlen, M., Flank, A.-M., Calas, G., Epping, E., 2007. Rapid postmortem incorporation of aluminium in diatom frustules: evidence from chemical and structural analyses. Marine Chemistry 106, 208-222.

Koshikawa, M.K., M., S., Hori, T., 2002. Seasonal variation of dissolved aluminum concentration in harmonic-type Lake Biwa, Japan. Limnology 3, $1-9$.

Labat, D., Godderis, Y., Probst, L., Guyot, J.L., 2004. Evidence for global runoff increase related to climate warming. Advances in Water Research 6, 631642.

Mackin, J.E., Aller, R.C., 1984. Diagenesis of dissolved aluminium in organicrich estuarine sediments. Geochimica et Cosmochimica Acta 48, 299-311.

McConnell, J.R., Aristarain, A.J., Banta, J.R., Edwards, P.R., Simoes, J.C., 2007. 20th-century doubling in dust archived in an Antarctic Peninsula ice core parallels climate change and desertification in South America. Proceedings 
of the National Academy of Science 104, 5743-5748.

Measures, C., Edmond, J.M., 1990. Aluminium in the South Atlantic: steady state distribution of a short residence time element. Journal of Geophysical Research, 95, 5331-5340.

Measures, C., Edmond, J.M., 1992. The distribution of aluminium in the Greenland Sea and its relationship to ventilation processes. Journal of Geophysical Research 97, 17787-17800.

Measures, C., Brown, E.T., 1996. Estimating dust input to the Atlantic Ocean using surface water Al concentrations. S. Guerzoni and R. Chester, The impact of desert dust across the Mediterranean. Springer, New York, 301311.

Measures, C.I., Brown, M.T., Vink, S., 2005. Dust depostition to the surface waters of the western and central North Pacific inferred from surface water dissolved aluminium concentrations. Geochemistry Geophysics Geosystems 6, doi:10.1029/2004GC000922.

Meredith, M.P., Renfrew, I.A., Clarke, A., King, J.C., Brandon, M.A., 2004. Impact of the 1997/1998 ENSO on upper ocean characteristics in Marguerite Bay, western Antarctic Peninsula. Journal of Geophysical Research 109, doi:10.1029/2003JC001784.

Meredith, M.P., King, J.C., 2005. Rapid climate change in the ocean west of the Antarctica Peninsula during the second half of the 20th century. Geophysical Research Letters 32, L19604, doi:19610.11029/12005GL024042.

Meredith, M.P., Brandon, M.A., Wallace, M.I., Clarke, A., Leng, M.J., Renfrew, I.A., van Lipzig, N.P.M., King, J.C., 2008. Variability in the freshwater balance of northern Marguerite Bay, Antarctic Peninsula: results from $\delta^{18} 0$. DeepSea Research II 55, 309-322.

Michalopoulos, P., Aller, R.C., 1995. Rapid clay mineral formation in Amazon delta sediments: reverse weathering and oceanic elemental cycles. Science 270, 614-617.

Michalopoulos, P., Aller, R.C., 2004. Early diagenesis of biogenic silica in the Amazon delta: alteration, authigenic clay formation, and storage. Geochimica Cosmochimica Acta 68, 1061-1085.

Moffat, C., Owens, B., Beardsley, R.C., 2009. On the characteristis of Circumpolar Deep Water intrusions to the west Antarctic Peninsula continental shelf. Journal of Geophysical Research 114, C05017, doi:05010.01029/02008JC004955.

Moran, S.B., Moore, R.M., 1992. Kinetics of the removal of dissoled Al by 
diatoms in seawater: a comparison with thorium. Geochimica Cosmochimica Acta 56, 3365-3374.

Orians, K.J., Bruland, K.W., 1986. The biogeochemistry of aluminium in the Pacific Ocean. Earth and Planetary Science Letters 78, 397-410.

Prendez, M., Carrasco, M.A., 2003. Elemental composition of surface waters in the Antarctic Peninsula and interactions with the environment. Environmental Geochemistry and Health, 25, 347-363.

Ren, J.L., Zhang, J., Li, J.B., Yu, X.Y., Liu, S.M., Zhang, E.R., 2006. Dissolved aluminium in the Yellow Sea and East China Sea - Al as a tracer of Changjiange (Yangtze River) discharge and Kuroshio incursion. Estuarine, Coastal and Shelf Science 68, 165-174.

Resing, J.A., Measures, C.I., 1994. Fluorometric determination of Al in seawater by flow injection analysis with in-line preconcentration. Analytical Chemistry 66, 4105-4111.

Rickert, D., Schluter, M., Wallman, K., 2002. Dissolution kinetics of biogenic silica from the water column to the sediments. Geochimica Cosmochimica Acta 66, 439-455.

Sañudo-Wilhelmy, S.A., Olsen, K.A., Scelfo, J.M., Foster, T.D., Flegal, A.R., 2002. Trace metal distributions off the Antarctic Peninsula in the Weddell Sea. Marine Chemistry 77, 157-170.

Shcherbina, A.Y., Talley, L.D., Rudnick, D.L., 2003. Direct observations of North Pacific ventilation: brine rejection in the Okhotsk Sea. Science, 302, 1952-1955.

Statham, P.J., Skidmore, M., Tranter, M., 2008. Inputs of glacially derived dissolved and colloidal iron to the coastal ocean and implications for primary productivity. Global Biogeochemical Cycles 22, doi:10.1029/2007GB003106.

Stoffyn-Egli, P., 1982. Dissolved aluminium in interstitial waters of recentterrigenous marine sediments from the North Atlantic Ocean. Geochimica et Cosmochimica Acta 46, 1345-1352.

Swift, J.H., Koltermann, K.P., 1988. The origin of the Norwegian Sea deep water. Journal of Geophysical Research 93, 3563-3569.

Talley, L.D., Lobanov, V., Ponomarev, V., Salyuk, A., Teshchenko, P., Zhabin, I., Riser, S., 2003. Deep convection and brine rejection in the Japan Sea. Geophysical Research Letters, 30, doi:10.1029/2002GL016451.

Tréguer, P., Nelson, D.M., Van Bennekom, A.J., DeMaster, D.J., Leynaert, A., Quéguiner, B., 1995. The silica balance in the world ocean: a reestimate. 
Science 268, 375-379.

Van Bennekom, A.J., 1981. On the role of aluminium in the dissolution kinetics of diatom frustules. Proceedings of the $6^{\text {th }}$ Diatom Symposium, 445454.

Van Bennekom, A.J., Buma, A.G.J., Notling, R.F., 1991. Dissolved aluminium in the Weddell-Scotia Confluence and effect of $\mathrm{Al}$ on the dissolution kinetics of biogenic silica. Marine Chemistry 35, 423-434.

Van Bennekom, A.J., Jansen, J.H.F., van der Gast, S.J., Van Iperen, J.M., Pieters, J., 1989. Aluminium-rich opal: an intermediate in the preservation of biogenic silica in the Zaire (Congo) deep sea fan. Deep-Sea Research 36, 173190.

Van Beusekom, J.E.E., Bennekom, A.J., Tréguer, P., Morvan, J., 1997. Aluminium and silicic acid in water and sediments of the Enderby and Crozet Basins. Deep-Sea Research 44, 987-1003.

Vink, S., Measures, C.I., 2001. The role of dust deposition in determining surface water distributions of $\mathrm{Al}$ and Fe in the South West Atlantic. Deep-Sea Research II 48, 2787-280.

Von Damm, K.L., 1995. Controls on the chemistry and temporal variability of seafloor hydrothermal fluids. In: Humphries, S., Ziernenberg, R. Mullineaux, L. Thomson, R.American Geophysical Union, Washington D.C., pp.

Wallace, M.I., Meredith, M.P., Brandon, M.A., Sherwin, T.J., Dale, A., Clarke, A., 2008. On the characteristics of internal tides and coastal upwelling behaviour in Marguerite Bay, West Antarctic Peninsula. Deep-Sea Research II (Palmer LTER Special Issue) 55, 2023-2040.

Weston, K. et al. (in prep for Deep-Sea Res.). Exportable and exported primary production in Marguerite Bay (western Antarctic Peninsula shelf): linking upper mixed layer production measurements and nutrient mass balance to sediment trap derived flux. 
Figure 1: Map of field study area. The stars show the location of the moorings and the RaTS site. Box cores were taken from near both mooring sites. Dashed lines show regional ocean circulation (dotted lines refer to ocean currents constrained with less certainty). Ocean circulation from C. Moffat and R. Beardsley (Woods Hole Oceanographic Institution), pers. comm. Bathymetry adapted from JR112 cruise report, M. Brandon (Open University).

Figure 2: Seawater chlorophyll a (Clarke et al., 2008; white squares), dissolved Al concentration ([Al], this study; black circles), particulate Al results (this study; grey hexagons), salinity (this study; black diamonds) and silicate $(\mathrm{Al} / \mathrm{Si})_{\text {total }}$ ratios (this study; grey triangles). Error bars on $(\mathrm{Al} / \mathrm{Si})_{\text {total }}$ data show reproducibility $\left(2 \sigma_{\mathrm{sd}}\right)$.

Figure 3: The $\mathrm{Al}$ content of opal collected by the sediment traps, (Al/Si) $)_{\text {opal. }}$ Error bars on $(\mathrm{Al} / \mathrm{Si})_{\text {opal }}$ data show reproducibility $\left(2 \sigma_{\mathrm{sd}}\right)$. The shaded period marks the sampling period for the water column measurements in Figure 2. The depths of each sediment trap are described in the text.

Figure 4A: Salinity, seawater $\delta^{18} 0(\%$, relative to SMOW) and the percentage contribution of sea ice melt and meteoric water melt to seawater at the RaTS site. The percentage of sea ice and meteoric water inputs are calculated from salinity and $\delta^{18} \mathrm{O}$ using mass balance equations (see text for details; Meredith et al., 2008). Horizontal timescale shows months.

Figure 4B: The Mixed Layer Depth (MLD) for the RaTS site in 2006 (see text for details). The MLD, shown by the grey area, is shallower than the sampling site, such that waters are collected from the top of the WW, until a sudden deepening in the middle of Febuary, followed by an MLD shoaling, and then a progressive deepening towards the end of summer/beginning of winter.

Figure 5: Vertical depth profiles of potential temperature (the temperature a parcel of water would acquire if it was adiabatically brought to 1000 millibars pressure), salinity, density and chlorophyll $a$ time series for the RaTS site. The ticks on the horizontal axes mark the actual sampling days.

Figure 6: A) Temperature and B) chlorophyll $a$ as a function of density and time.

Figure 7: Cartoon illustrating the supply of Al to the deep waters through brine rejection. The percentage contribution of each dissolved Al concentration source is calculated using seawater $\delta^{18} 0$ and salinity (Equations 1-3). In the late summer (March), there is a deep Mixed Layer (ML) and strong meteoric input due to glacial melt. In the following months (April-May), sea ice melting stops and formation begins from relatively $\mathrm{Al}$ enriched waters; brine rejection from this formation process enriches the deeper waters further through resuspension of sediments as the brine plumes cascade down the slope. The sea ice formation processes results in a well mixed water layer. The shallow pycnocline forms in the spring, when melting freshens the surface. In the following summer (in this case Feb 2006), upwelling and mixing events bring 
the enriched waters to the sampling depth $(15 \mathrm{~m})$. Note the non-linear vertical axis.

Table 1: Sea ice dissolved aluminium, where [Al] is the concentration of dissolved Al.

\begin{tabular}{|c|c|c|c|}
\hline Date & Sample type & {$[\mathrm{Al}] \mathrm{nM}$} & Chl $a\left(\mathrm{mg} \mathrm{m}^{-3}\right)$ \\
\hline $21 / 11 / 2005$ & $\begin{array}{c}\text { Sea ice } \\
\text { interstitial water } \\
\text { Sea ice } \\
\text { interstitial water } \\
\text { Sea ice }\end{array}$ & 21.70 & 2.76 \\
$06 / 12 / 2005$ & $\begin{array}{c}\text { interstitial water } \\
\text { Sea ice } \\
09 / 12 / 2005\end{array}$ & 22.57 & 1.33 \\
$20 / 12 / 2005$ & $\begin{array}{c}\text { interstitial water } \\
\text { Sea ice } \\
\text { interstitial water }\end{array}$ & 17.26 & 0.91 \\
$21 / 11 / 2005$ & Under ice water & 9.34 & 1.77 \\
$23 / 12 / 2005$ & Under ice water & 8.33 & 0.04 \\
& & 30.25 & 0.05 \\
\hline
\end{tabular}




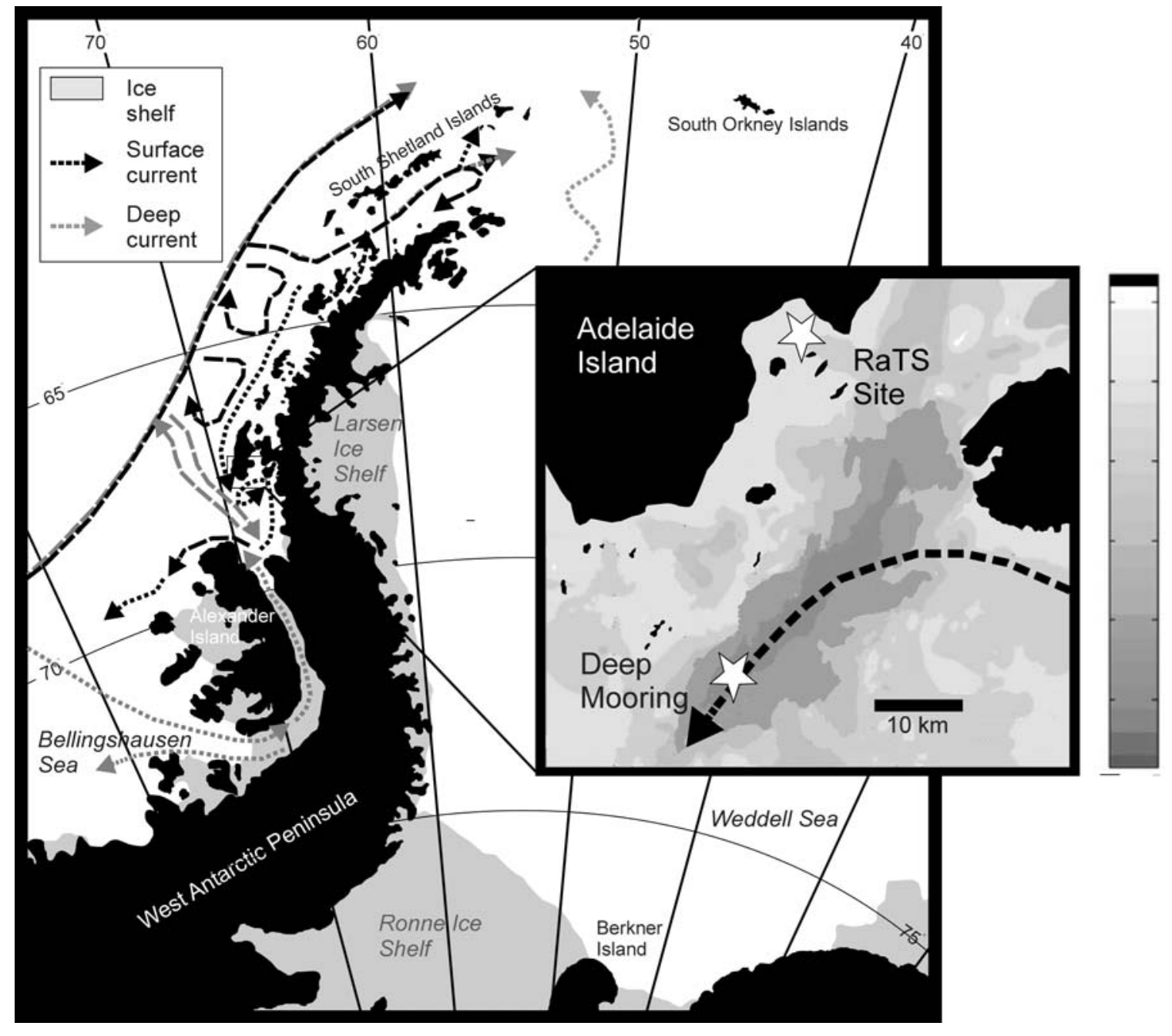


Date

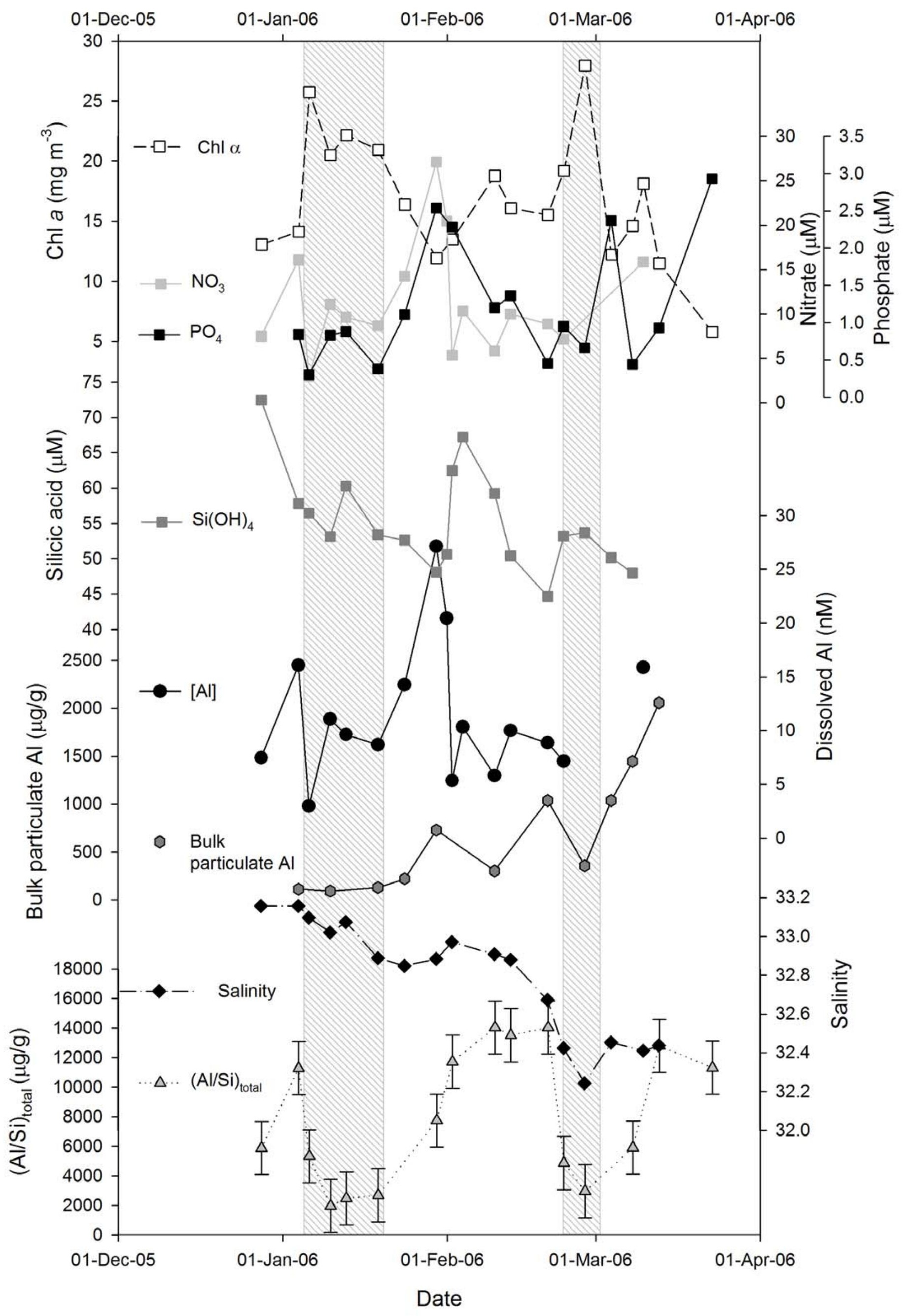




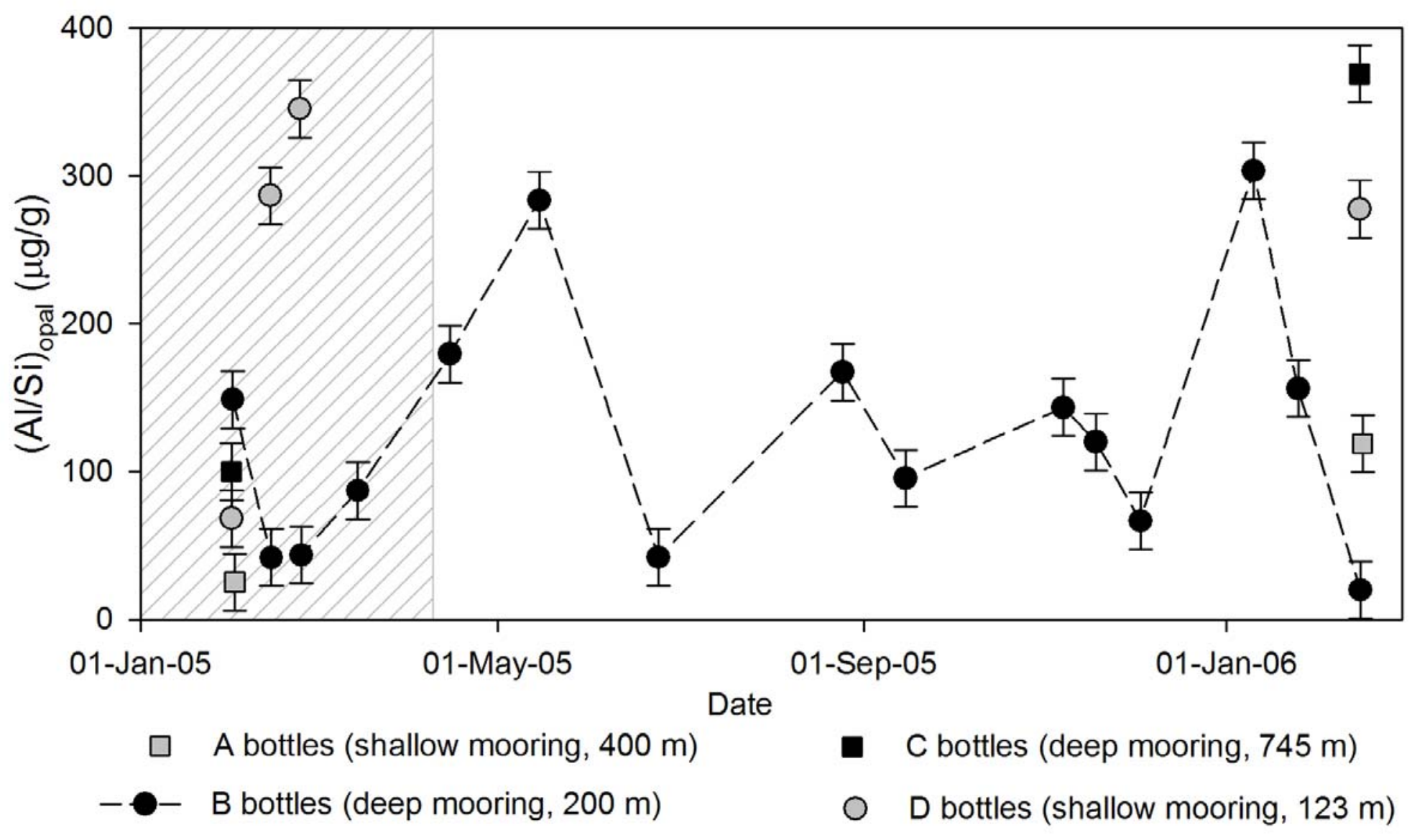



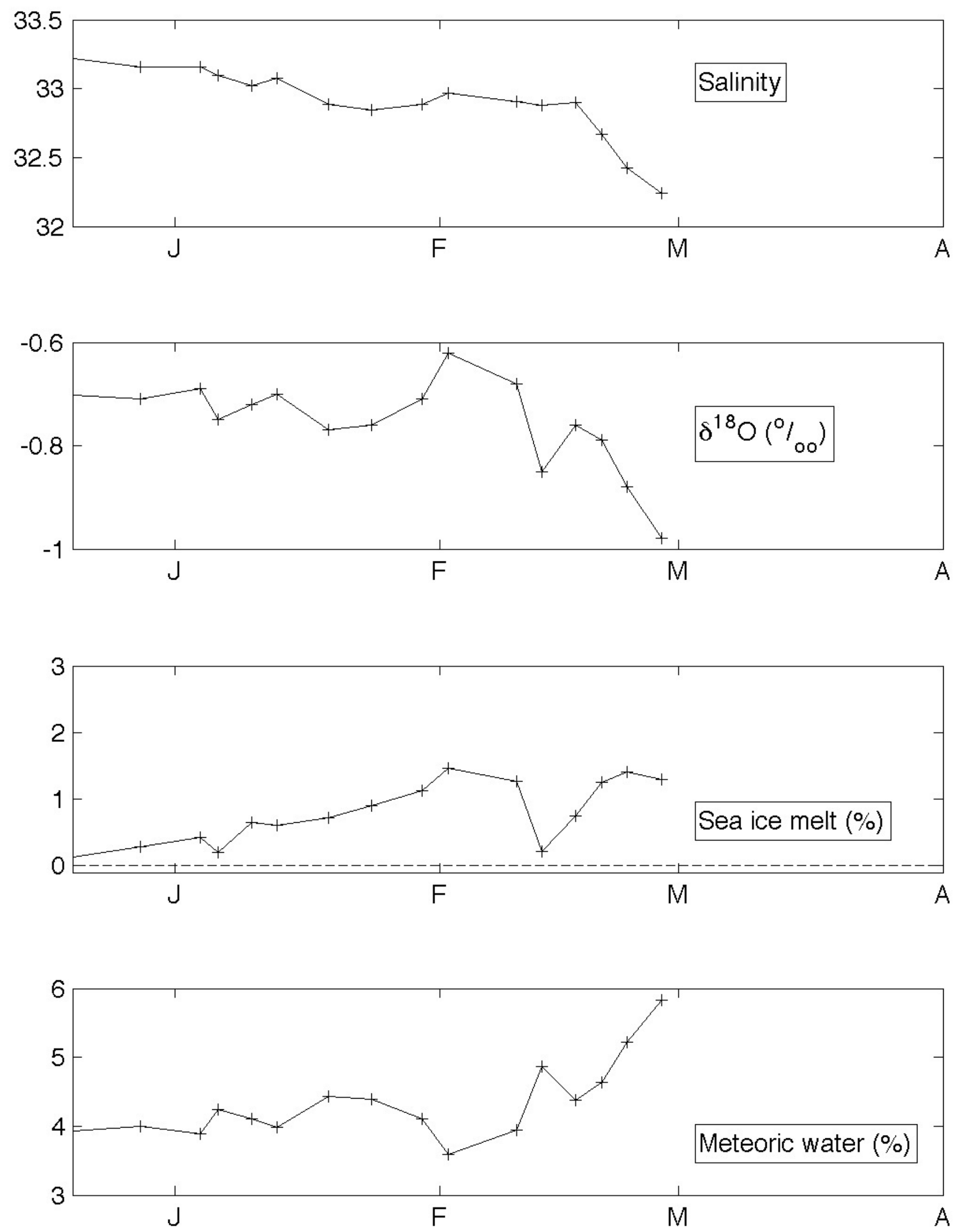


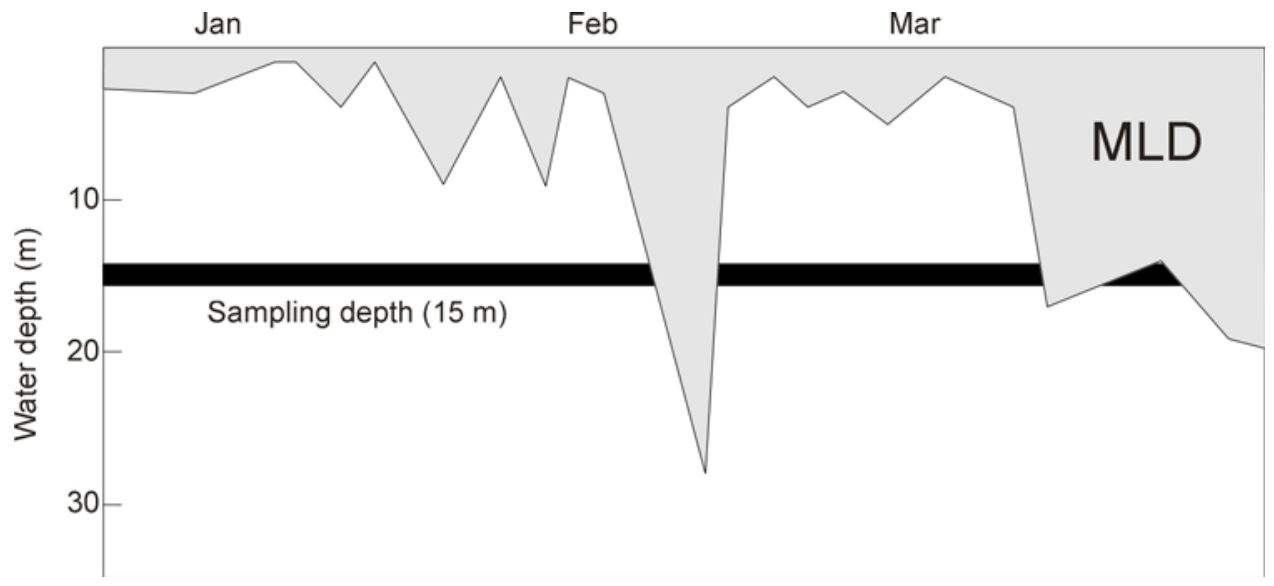




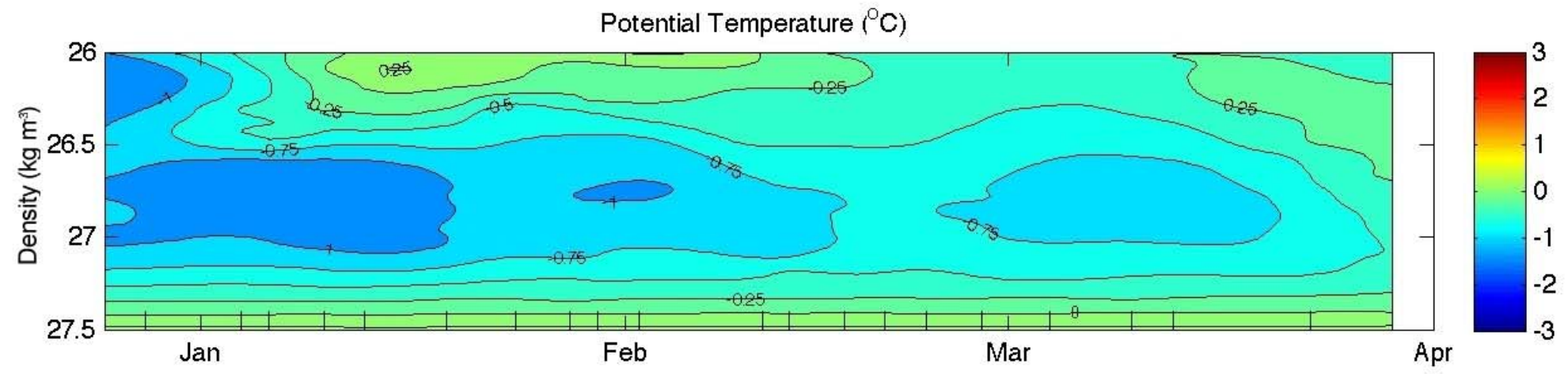




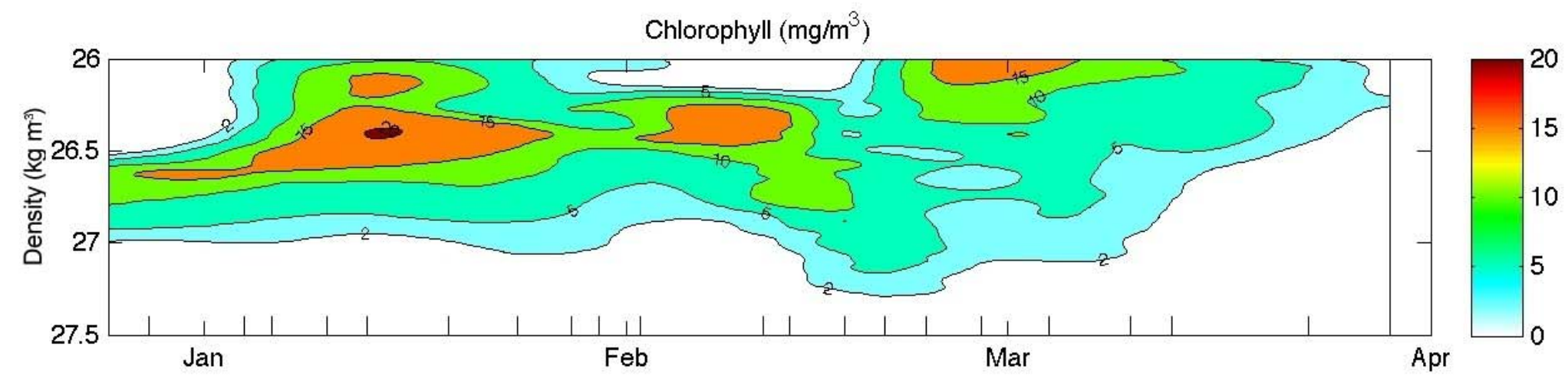



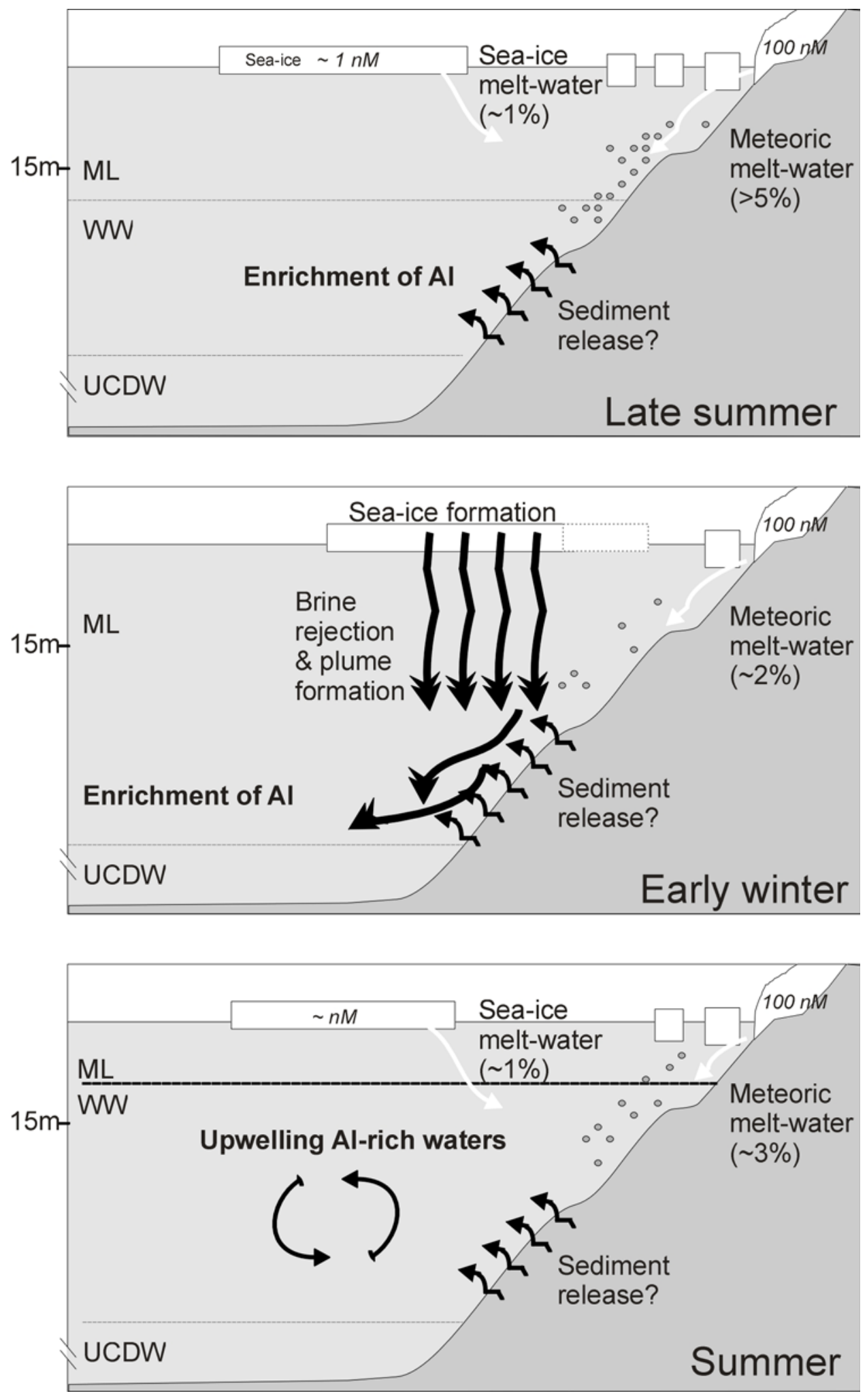